\title{
Kooperatif Tipe Think Pair Share terhadap Hasil Belajar Tematik Siswa Sekolah Dasar
}

\author{
Yudha Popiyanto \\ popiyanto83@gmail.com \\ Pendidikan Guru Sekolah Dasar, Fakultas Bahasa dan Sains, \\ Universitas Wijaya Kusuma Surabaya.
}

\begin{abstract}
Cooperative type Think Pair Share is learning that prioritizes ways of cooperating or grouping and opportunities for students to be more active and interactive to foster the courage of students to think and respect the opinions of other students, thus fostering students' confidence in expressing opinions and answering teacher questions verbally or in writing in the thematic learning process in Elementary School (SD). Cooperative objectives of the Think Pair Share type improve thematic learning outcomes to meet and exceed the value of the Minimum Completion Criteria (KKM) of elementary school (SD) students. This research approach uses quantitative and experimental research types, carried out systematically, logically, and thoroughly in a controlled conditioning process. Quasi control group design experimental design through cooperative type Think Pair Share on thematic learning outcomes of third grade students of SDN 2 Kedamean Gresik Regency. The results of the study obtained conclusions of the test results of the independent sample t-test obtained were $0.003<0.05$. Thus, $H_{0}$ is rejected and $H_{a}$ is accepted, which means that there is a cooperative influence of the Think Pair Share type on the thematic learning outcomes of the students of SDN 2 Kedamean, Gresik Regency.
\end{abstract}

Keywords: Cooperative type Think Pair Share, Learning Outcomes, Thematic.

\begin{abstract}
Abstrak
Kooperatif tipe Think Pair Share merupakan pembelajaran yang memprioritaskan cara bekerjasama atau berkelompok dan kesempatan kepada siswa lebih aktif dan interaktif untuk menumbuhkan keberanian siswa berpendapat serta menghargai pendapat siswa lain, sehingga menumbuhkan rasa percaya diri siswa untuk menyampaikan suatu pendapat serta menjawab pertanyaan guru secara lisan maupun tulisan dalam proses pembelajaran tematik di Sekolah Dasar (SD). Tujuan kooperatif tipe Think Pair Share meningkatkan hasil belajar tematik untuk memenuhi dan melampaui nilai Kriteria Ketuntasan Minimal (KKM) pembelajaran tematik siswa Sekolah Dasar (SD). Pendekatan penelitian ini menggunakan kuantitatif dan jenis penelitian eksperimen, dilakukan secara sistematis, logis, dan teliti dalam proses pengkondisian yang terkontrol. Desain penelitian eksperimental quasi control group design melalui kooperatif tipe Think Pair Share terhadap hasil belajar tematik siswa kelas III SDN 2 Kedamean Kabupaten Gresik. Hasil penelitian diperoleh simpulan hasil uji independent sample t-test yang diperoleh yaitu $0,003<0,05$. Dengan demikian maka $\mathrm{H}_{0}$ ditolak dan $\mathrm{H}_{\mathrm{a}}$ diterima yang artinya ada pengaruh kooperatif tipe Think Pair Share terhadap hasil belajar tematik siswa SDN 2 Kedamean Kabupaten Gresik.
\end{abstract}

Kata Kunci : Kooperatif tipe Think Pair Share, Hasil belajar, Tematik. 


\section{PENDAHULUAN}

Pendidikan sebagai proses pembelajaran antara siswa berinteraksi dengan sumber belajar yang berupaya membantu siswa dalam penguasaan kognitif, psikomotorik, dan afektif. Interaksi pendidikan dapat berlangsung di lingkungan informal, formal, dan nonformal. Pendidikan formal menurut Sukmadinata (2010:2), memiliki beberapa kelebihan sebagai berikut: Pertama, mempunyai rancangan pendidikan atau kurikulum tertulis yang tersusun secara sistematis, jelas, dan rinci. Kedua, lingkup isi pendidikan lebih tinggi, lebih luas, serta mendalam yang berkenaan dengan ilmu pengetahuan, keterampilan, dan pembinaan sikap maupun moral. Ketiga, mendapatkan pengawasan, bimbingan, dan penilaian dari pendidik yang memiliki ilmu pengetahuan serta keterampilan, khususnya bidang ilmu pendidikan. Keempat, difasilitasi sarana prasarana yang disertai peraturan-peraturan tertulis.

Berdasarkan pengamatan awal, proses pembelajaran tematik siswa kelas III SDN 2 Kedamean Kabupaten Gresik masih menerapkan paradigma transformative learning berbasis teacher centered or teacher oriented, sehingga menyebabkan hasil belajar sebagian siswa di bawah nilai Kriteria Ketuntasan Minimal (KKM). Pendekatan teacher centered or teacher oriented, sudah dianggap tradisional dan perlu beralih pada learner centered or learner oriented sebagai pembelajaran berpusat pada siswa (Amir, 2010:3). Pendekatan learner centered or learner oriented menerapkan paradigma active learning yang memfokuskan terhadap keterampilan belajar siswa dalam pembelajaran tematik untuk meningkatkan

pengembangan kemampuan siswa dalam membangun sendiri pengetahuan baru melalui proses berpikir mensintesis pengetahuan serta pengalaman lama dan baru dalam proses pembelajaran tematik di kelas.

Learner centered or learner oriented dapat mengimplementasikan model pembelajaran kooperatif. Kooperatif merupakan suatu model pembelajaran yang menarik bagi siswa, karena model pembelajaran ini merupakan suatu model pembelajaran dengan cara bekerjasama atau berkelompok (Suprijono, 2014:54). Kooperatif ini didasarkan pada falsafah homo homini socius. Manusia adalah makhluk sosial yang berdialog interaktif (interaksi sosial) merupakan kunci seseorang dapat menempatkan dirinya di lingkungan sekitar (Slavin, 2010:4). Unsur-unsur dalam pembelajaran kooperatif sebagai berikut: (a). Para siswa harus memiliki persepsi bahwa mereka "tenggelam atau berenang bersama"; (b). Para siswa harus memiliki tanggung jawab terhadap siswa atau siswa lain dalam kelompoknya, selain tanggung jawab terhadap diri sendiri dalam mempelajari materi yang dihadapi; (c). Para siswa harus berpendapat bahwa mereka semua memiliki tujuan yang sama; (d). Para siswa membagi tugas dan berbagi tanggung jawab di antara para anggota kelompok; (e). Para siswa diberikan satu evaluasi atau penghargaan yang akan ikut berpengaruh terhadap evaluasi kelompok; (f). Para siswa berbagi kepemimpinan sementara mereka memperoleh keterampilan bekerja sama selama belajar.

Setiap siswa akan diminta mempertanggung jawabkan secara individual materi yang ditangani 
dalam kelompok kooperatif. Kooperatif memiliki beberapa macam tipe, salah satunya kooperatif tipe Think Pair Share yang memberi siswa waktu untuk berpikir dan merespon serta saling bantu satu sama lain (Shoimin, 2014:09). Kooperatif tipe Think Pair Share dengan sintaks: guru menyajikan materi klasik, berikan persolan kepada siswa dan siswa bekerja kelompok dengan cara pasangan sebangku-bangku (thinkpair), presentasi kelompok (share), kuis individual, buat skor perkembangan siswa, umumkan hasil kuis dan reward (Ngalimun, 2012:169).

Menurut Shoimin (2014:211) ada beberapa langkah model Think Pair Share yaitu: (a). Tahap satu, think (berpikir) adalah pada langkah berpikir ini guru memberikan pertanyaan dengan yang terkait dengan materi pelajaran. Proses Think Pair Share dimulai pada saat ini, yaitu guru mengemukakan pertanyaan yang menggalakkan berpikir ke seluruh kelas. Pertanyaan ini hendaknya berupa pertanyaan terbuka yang memungkinkan dijawab dengan berbagai macam jawaban; (b). Tahap dua, pair (berpasangan) adalah pada tahap ini siswa berpikir secara individu. Guru meminta kepada siswa untuk berpasangan dan mulai memikirkan pertanyaan atau masalah yang diberikan guru dalam waktu tertentu. Lamanya waktu ditetapkan berdasarkan pemahaman guru terhadap siswanya, sifat pertanyaannya, dan jadwal pelajaran. Siswa disarankan untuk menulis jawaban atau pemecahan masalah hasil pemikirannya; (c). Tahap tiga, share (berbagi) adalah pada tahap ini siswa secara individu mewakili kelompok atau berdua maju bersama untuk melaporkan hasil diskusinya ke seluruh kelas. Pada tahap terakhir ini siswa seluruh kelas akan memperoleh keuntungan dalam bentuk mendengarkan berbagai ungkapan mengenai konsep yang sama dinyatakan dengan cara berbeda oleh individu yang berbeda.

Think Pair Share memberikan kesempatan kepada siswa untuk lebih aktif dan interaktif dalam pembelajaran tematik di kelas. Menumbuhkan keberanian siswa berpendapat dan menghargai pendapat siswa lain, sehingga meningkatkan rasa percaya diri siswa dalam menyampaikan suatu pendapat serta dalam menjawab pertanyaan guru secara lisan maupun tulisan. Implementasi Think Pair Share dapat memberikan kesempatan kepada siswa untuk berinteraksi dengan kelompok dan membagikan hasil maupun informasi kepada seluruh teman sekelasnya, sehingga diharapkan dapat meningkatkan hasil belajar tematik. Kooperatif tipe Think Pair Share memiliki berbagai kelebihan.

Menurut Shoimin (2014:211) kelebihan Think Pair Share yaitu: (a). Think Pair Share mudah diterapkan di berbagai jenjang pendidikan dan dalam setiap kesempatan; (b). Menyediakan waktu berpikir untuk meningkatkan kualitas respons siswa; (c). Siswa menjadi lebih aktif dalam berpikir mengenai konsep dalam mata pelajaran; (d). Siswa lebih memahami tentang konsep topik pelajaran selama diskusi; (d). Siswa dapat belajar dari siswa lain; (e). Setiap siswa dalam kelompoknya mempunyai kesempatan untuk berbagi atau menyampaikan idenya sehingga meningkatkan hasil belajar.

Hasil belajar sebagaimana diuraikan oleh Nawawi (dalam Susanto, 2014:5) yang menyatakan 
bahwa hasil belajar dapat diartikan sebagai tingkat keberhasilan siswa dalam mempelajari materi pelajaran di sekolah yang dinyatakan dalam skor yang diperoleh dari hasil tes mengenal sejumlah materi pelajaran tertentu. Secara sederhana, hasil belajar siswa adalah kemampuan yang diperoleh anak setelah melalui kegiatan belajar sendiri karena belajar itu sendiri merupakan suatu proses dari seseorang yang berusaha untuk memperoleh suatu bentuk perubahan perilaku yang relatif menetap (Susanto, 2014:5). Hasil belajar yang baik tentu merupakan tujuan dari sebuah proses pembelajaran. Namun, kadangkala hasil tersebut tidak sesuai yang diharapkan dikarenakan faktorfaktor tertentu yang menyebabkan timbulnya kesulitan belajar mengajar. Hasil belajar yang dicapai oleh siswa merupakan hasil interaksi antara berbagai faktor yang mempengaruhi, baik faktor internal maupun eksternal.

Menurut Wasliman (dalam Susanto, 2014 : 12), uraian mengenai faktor internal dan eksternal, sebagai berikut: (a). Faktor internal adalah faktor internal ini meliputi: kecerdasan, minat dan perhatian, motivasi belajar, ketekunan, sikap, kebiasaan belajar, serta kondisi fisik dan kesehatan; (b). Faktor eksternal adalah faktor yang berasal dari luar siswa yang mempengaruhi hasil belajar yaitu keluarga, sekolah, dan masyarakat. Hasil belajar siswa adalah kemampuan yang diperoleh anak setelah melalui kegiatan belajar sendiri karena belajar itu sendiri merupakan suatu proses dari seseorang yang berusaha untuk memperoleh suatu bentuk perubahan perilaku relatif menetap atas keberhasilan siswa dalam memahami materi pembelajaran yang dinyatakan dalam skor terhadap hasil tes pembelajaran tematik.

Pembelajaran tematik adalah salah satu bentuk atau model dari pembelajaran terpadu, yaitu model terjala yang pada intinya menekankan pada pola pengorganisasian materi yang terintegrasi dipadukan oleh suatu tema. Tema diambil dan dikembangkan dari luar mata pelajaran, tapi sejalan dengan kompetensi dasar dan topik-topik (standar isi) dari mata pelajaran. Pembelajaran tematik lebih menekankan pada keterlibatan siswa dalam proses belajar atau mengarahkan siswa secara aktif terlibat dalam proses pembelajaran (Rusman, 2010:254). Melalui pembelajaran tematik siswa dapat memperoleh pengalaman langsung dan terlatih untuk dapat menemukan sendiri berbagai pengetahuan yang dipelajari secara holistik, bermakna, otentik, dan aktif.

Menurut Rusman (2010:258) pembelajaran tematik memiliki karakteristik sebagai berikut: (a). Berpusat kepada siswa, pembelajaran tematik berpusat kepada siswa ini sesuai dengan pendekatan modern yang lebih banyak menempatkan siswa sebagai subjek belajar, sedangkan guru lebih banyak berperan sebagai fasilitator, yaitu memberikan kemudahan-kemudahan kepada siswa; (b). Memberikan pengalaman langsung, pembelajaran tematik dapat memberikan pengalaman langsung pada siswa. Dengan pengalaman langsung ini siswa dihadapkan pada sesuatu yang nyata sebagai dasar dalam memahami hal-hal yang abstrak; (c). Pemisahan mata pelajaran tidak begitu jelas, dalam pembelajaran tematik pemisahan antar mata pelajaran menjadi tidak begitu jelas. Fokus 
pembelajaran diarahkan pada pembahasan tema-tema yang paling dekat berkaitan dengan kehidupan siswa; (d). Menyajikan konsep dari berbagai mata pelajaran, pembelajaran tematik menyajikan konsep-konsep dari berbagai mata pelajaran dalam suatu proses pembelajaran. Dengan demikian siswa dapat memahami konsepkonsep tersebut secara utuh. Hal ini diperlukan untuk membantu siswa dalam memecahkan masalah-masalah yang dihadapi dalam kehidupan sehari-hari; (e). Bersifat fleksibel, pembelajaran tematik bersifat luwes (fleksibel) dimana guru dapat mengaitkan bahan ajar dari satu mata pelajaran dengan mata pelajaranyang lainnya, bahkan mengaitkan dengan kehidupan siswa dan keadaan lingkungan di mana sekolah dan siswa berada; (f). Hasil pembelajaran sesuai dengan minat dan kebutuhan siswa, siswa diberi kesempatan untuk mengoptimalkan potensi yang dimilikinya sesuai dengan minat dan kebutuhannya; (g). Menggunakan prinsip belajar sambil bermain dan menyenangkan, guru dan siswa dapat membuat suatu prinsip dalam pembelajaran. Sehingga guru dan siswa dapat bermain sambil belajar. Sehingga proses belajar mengajar menjadi menyenangkan.

Berdasarkan beberapa hal di atas, prioritasnya berupaya meningkatkan hasil belajar tematik siswa, sehingga dapat memenuhi dan melampaui nilai Kriteria Ketuntasan Minimal (KKM) pembelajaran tematik. Penelitian ini tentang kooperatif tipe Think Pair Share terhadap hasil belajar tematik pada siswa kelas III SDN 2 Kedamean Kabupaten Gresik.

\section{METODE PENELITIAN}

Pendekatan penelitian ini menggunakan kuantitatif karena dan jenis penelitian eksperimen, dilakukan secara sistematis, logis, dan teliti dalam proses pengkondisian yang terkontrol. Penelitian eksperimen memberikan kebebasan pada peneliti untuk memanipulasi suatu stimuli, kondisi-kondisi eksperimental, kemudian mengobservasi pengaruh yang diakibatkan oleh adanya perlakuan atau manipulasi tersebut (Riyanto, 2007:120).

Penelitian eksperimen untuk menguji hipotesis terdiri dari tiga kategori, yaitu; 1) pra eksperimen, 2) eksperimen semu, dan 3) eksperimen murni. Penelitian ini menggunakan pola rancangan penelitian eksperimen semu Desain penelitian menggunakan penelitian eksperimental quasi control group design melalui kooperatif tipe Think Pair Share terhadap hasil belajar tematik siswa kelas III SDN 2 Kedamean Kabupaten Gresik.

Sebelum pembelajaran dimulai, pada kelas kontrol maupun kelas eksperimen diberikan pretest untuk mengetahui sejauh mana pemahaman tentang mata pelajaran tematik, dan setelah selesai pembelajaran masingmasing kelas diberi posttest.

Tabel 1. Perlakuan/ Treatment

\begin{tabular}{|c|c|c|c|}
\hline Kelas & $\begin{array}{c}\text { Pengukur } \\
\text { an Awal } \\
\text { (pretest) }\end{array}$ & $\begin{array}{c}\text { Perlaku } \\
\text { an } \\
(\text { Treat } \\
\text { ment })\end{array}$ & $\begin{array}{c}\text { Pengukur } \\
\text { an Akhir } \\
\text { (posttest) }\end{array}$ \\
\hline Eksperimen & $\mathrm{O} 1$ & $\mathrm{X}$ & $\mathrm{O} 2$ \\
\hline Kontrol & $\mathrm{O} 3$ & - & $\mathrm{O} 4$ \\
\hline
\end{tabular}

Pada skema di atas dijelaskan bahwa sebelum memberikan perlakuan, kedua kelompok diberi tes awal (pretest) untuk mengukur 
kondisi awal, selanjutnya kelas kontrol tidak diberi perlakuan dan kelompok eksperimen diberi perlakuan (X). Sesudah selesai memberikan perlakuan kedua kelompok diberi tes lagi sebagai tes akhir (posttest).

Variabel bebas penelitian ini adalah kooperatif tipe Think Pair Share (X). Variabel terikat penelitian ini adalah hasil belajar (Y). Subyek penelitian adalah siswa kelas III SDN 2 Kedamean Kabupaten Gresik. Tempat penelitian SDN 2 Kedamean Kabupaten Gresik. Sedangkan waktu penelitian dilakukan pada semester genap tahun pelajaran 2018/2019.

Penelitian ini menggunakan seperangkat instrument berbentuk test. Tes merupakan sejumlah pertanyaan yang membutuhkan jawaban, hal ini digunakan untuk mendapatkan data kooperatif tipe Think Pair Share terhadap hasil belajar tematik pada siswa kelas III SDN 2 Kedamean Kabupaten Gresik. Instrument ini digunakan untuk melihat hasil belajar siswa, berupa tes tertulis berbentuk tes obyektif. Tes ini disusun berdasarkan indikator, kompetensi inti, dan kompetensi dasar pembelajaran tematik pada siswa kelas III SDN 2 Kedamean Kabupaten Gresik. Selain itu peneliti juga menggunakan instrument berbentuk angket. Pada penelitian ini peneliti menggunakan angket tertutup, dimana responden tinggal memberikan tanda centang $(\sqrt{ })$ pada alternatif jawaban yang telah tersedia. Tujuan dari penggunaan angket adalah untuk mengetahui hasil belajar tematik siswa setelah menggunakan kooperatif tipe Think Pair Share di kelas III SDN 2 Kedamean Kabupaten Gresik.

Penguji hipotesis apakah ada pengaruh yang signifikan model pembelajaran kooperatif tipe Think Pair Share terhadap hasil belajar tematik pada siswa kelas III SDN 2 Kedamean Kabupaten Gresik, maka digunakan analisis data. Berdasarkan uraian maka hipotesis dalam penelitian ini sebagai berikut: Ho: Model pembelajaran kooperatif tipe Think Pair Share tidak berpengaruh terhadap hasil belajar tematik pada siswa kelas III SDN 2 Kedamean Kabupaten Gresik. Ha: Model pembelajaran kooperatif tipe Think Pair Share berpengaruh terhadap hasil belajar tematik pada siswa kelas III SDN 2 Kedamean Kabupaten Gresik. Sebelum dilakukan analisis data untuk pengujian hipotesis, terlebih dahulu dilakukan uji asumsi analisis yaitu; uji normalitas, uji homogenitas, dan uji hipotesis.

Uji normalitas bertujuan untuk mengetahui apakah data berdistribusi normal atau tidak. Hipotesis statistik yang digunakan pada uji normalitas adalah: Uji normalitas dilakukan untuk mengetahui sebaran data mengikuti sebaran baku normal atau tidak. Normalitas hanya dikenakan pada variabel terikat/ dependen $(\mathrm{Y})$. Uji normalitas menggunakan Kolmogorow-Smirnow. Kriteria sebaran data menunjukan normal jika Lh > 0,05. Untuk pengujian normalitas digunakan komputerisasi dengan program SPSS 21 For Windows Evaluation Version. Uji homogenitas menggunakan bantuan komputer program SPSS 21 For Windows Evaluation Version. Pengujian hipotesis menggunakan independent sample t-test. Analisis data independent sample t-test digunakan untuk mengukur apakah ada perbedaan hasil belajar antara kelompok eksperimen dan kelompok kontrol. Untuk melakukan uji independent sample t-test digunakan 
bantuan program SPSS 21 For Windows Evaluation Version. Dasar pengambilan keputusan adalah berdasarkan perbandingan $t_{\text {hitung }}$ dengan $t_{\text {tabel }}$ pada derajat kesalahan 5\% (Sugiyono, 2012:230) dengan keterangan:

a. Jika $t_{\text {hitung }}$ lebih besar dari $t_{\text {tabel }}\left(t_{\text {hitung }}>t_{\text {tabel }}\right), \quad$ maka hipotesis nihil (Ho) yang diajukan ditolak dan hipotesis alternatif (Ha) diterima.

b. Jika $t_{\text {hitung }}$ lebih kecil dari $t_{\text {tabel }}\left(t_{\text {hitung }}<t_{\text {tabel }}\right)$, maka hipotesis nihil (Ho) yang diajukan diterima dan hipotesis alternatif (Ha) ditolak.

Uji hipotesis untuk mengetahui pengaruh kooperatif tipe Think Pair Share, uji hipotesis yang digunakan adalah uji $t$ dengan mencari perbedaan dua sampel. Untuk menguji perbedaan hasil belajar pada kelompok kontrol dan kelompok eksperimen, digunakan uji paired sampel $T$ dan independent sampel test.

$$
\begin{gathered}
t=\frac{x_{1}-x_{z}}{\sqrt{\frac{s_{1}^{z}}{n_{1}}+\frac{g_{z}^{z}}{n_{1}}}} \\
t=\frac{x_{1}-x_{2}}{\sqrt{\frac{\left(n_{1}-1\right) s_{1}^{2}+\left(n_{2}-1\right) s_{2}^{2}}{n_{1}+n_{2}-2}\left(\frac{1}{n_{1}}+\frac{1}{n_{2}}\right)}}
\end{gathered}
$$

(Sugiyono, 2010:197)

Dimana:

$\mathrm{t}=$ nilai $\mathrm{t}$ yang dihitung

$\mathrm{x} 1=$ nilai rata-rata kelompok kontrol $\mathrm{x} 2=$ nilai rata-rata kelompok eksperimen

$\mathrm{S} 1$ = simpangan baku kelompok kontrol

$\mathrm{S} 2$ = simpangan baku kelompok eksperimen

$\mathrm{n} 1=$ jumlah anggota kelompok kontrol

$\mathrm{n} 2=$ jumlah anggota kelompok eksperimen

Untuk menguji hipotesi nol, kriterianya adalah:

Tolak $\mathrm{H}_{0}$, jika Thitung < Ttabel

Terima $\mathrm{H}_{0}$, jika Thitung > Ttabel

Selain itu juga menggunakan Anava Regresi Linear Sederhana. Regresi linier mengestimasi besarnya koefisien-koefisien yang dihasilkan dari persamaan yang bersifat linier, yang melibatkan satu variabel bebas, untuk digunakan sebagai alat prediksi besarnya nilai variabel bergantung (Sawono, 2013). Anava regresi linier sederhana digunakan dalam penelitian ini untuk membuktikan hubungan antara variabel $(\mathrm{X})$ dan variabel $(\mathrm{Y})$.

$$
Y=a+b X
$$

(Sugiyono, 2010:261)

Dimana:

$\mathrm{Y}=$ Nilai yang diprediksikan

$\mathrm{a} \quad=$ Konstanta atau bila harga $\mathrm{X}$

$=0$

$\mathrm{b}=$ Koefisien regresi

$\mathrm{X}=$ Nilai variabel independen

Uji statistika yang digunakan adalah uji F

$$
\mathrm{F}=\frac{s 2 \mathrm{reg}}{s 2 \operatorname{sis}}
$$

Untuk menguji hipotesi nol, kriterianya adalah :

Tolak $\mathrm{H}_{0}$, jika Fhitung < Ftabel 
Terima $\mathrm{H}_{0}$, jika Fhitung > Ftabel

Proses penghitungan uji paired sampel $T$ test dan analisis anava penelitian ini menggunakan program SPSS 21 For Windows Evaluation Version.

\section{HASIL DAN PEMBAHASAN}

Analisis data hasil tes dilakukan untuk menguji kooperatif tipe Think Pair Share berpengaruh terhadap hasil belajar tematik siswa kelas III SDN 2 Kedamean Kabupaten Gresik. Sebelum peneliti melakukan pengujian terhadap hipotesis penelitian, terlebih dahulu akan dianalisis mengenai normalitas dan homogenitas data dari kelas eksperimen maupun kelas kontrol. Data yang akan dianalisis adalah data hasil belajar dalam bentuk pretest dan posttest.

a. Uji Normalitas

Uji normalitas adalah uji yang digunakan untuk mengukur data berdistribusi normal atau tidak. Uji normalitas data dibagi menjadi dua yaitu Kolmogorov-Smirnov dan Shapiro-Wilk. Kolmogorov-Smirnov digunakan untuk menguji normalitas pada sampel besar diatas 50, sedangkan Shapiro-Wilk digunakan untuk menguji normalitas pada sampel kecil dibawah 50 (Pramesti, 2014:204).

Tabel 2. Uji Normalitas Pretest

\begin{tabular}{|l|l|r|r|r|}
\hline \multirow{2}{*}{} & KELAS & \multicolumn{3}{|c|}{ Shapiro-Wilk } \\
\cline { 3 - 5 } & & $\begin{array}{c}\text { Statist } \\
\text { ic }\end{array}$ & df & Sig. \\
\hline $\begin{array}{l}\text { PRETE } \\
\text { ST }\end{array}$ & $\begin{array}{l}\text { Eksperim } \\
\text { en }\end{array}$ &, 902 & 19 &, 052 \\
Kontrol &, 948 & 19 &, 372 \\
\hline
\end{tabular}

Berdasarkan tabel uji normalitas pretest diketahui hasil uji normalitas pretest dengan menggunakan shapiro-wilk. Pada kelas eksperimen, kolom statistic merupakan nilai hitung uji normalitas yaitu 0,902 dengan kolom degree of freedom $(d f)$ atau derajat kebebasan yang merupakan jumlah sampel yaitu 19 siswa dengan kolom signifikan yang merupakan tingkat keyakinan terhadap suatu hipotesis yaitu 0,052 . Sedangkan pada kelas kontrol, kolom statistic merupakan nilai hitung uji normalitas yaitu 0,948 dengan kolom degree of freedom $(d f)$ atau derajat kebebasan yang merupakan jumlah sampel yaitu 19 siswa dengan kolom signifikan yang merupakan tingkat keyakinan terhadap suatu hipotesis yaitu 0,372 .

Berdasarkan hasil pengujian statistik menggunakan bantuan software Statistical Product and Service Solution (SPSS), untuk membaca uji Shapiro-Wilk hanya melihat pada kolom signifikansi. Signifikansi pada kelas eksperimen yaitu 0,052 dan untuk kelas kontrol yaitu 0,372. Karena signifikansi kelas eksperimen dan kelas kontrol >0,05 maka dapat disimpulkan bahwa data penelitian berdistribusi normal.

Tabel 3. Uji Normalitas Posttest

\begin{tabular}{|l|l|r|r|r|}
\hline \multirow{2}{*}{} & KELAS & \multicolumn{3}{|c|}{ Shapiro-Wilk } \\
\cline { 3 - 5 } & & $\begin{array}{c}\text { Statis } \\
\text { tic }\end{array}$ & df & Sig. \\
\hline POST & $\begin{array}{l}\text { Eksperi } \\
\text { men }\end{array}$ &, 906 & 19 &, 062 \\
TEST & Kontrol &, 909 & 19 &, 072 \\
\hline
\end{tabular}

Berdasarkan tabel uji normalitas posttest diketahui hasil uji normalitas posttest dengan menggunakan shapiro-wilk. Pada kelas eksperimen, kolom statistic merupakan nilai 
hitung uji normalitas yaitu 0,906 dengan kolom degree of freedom (df) atau derajat kebebasan yang merupakan jumlah sampel yaitu 19 siswa dengan kolom signifikan yang merupakan tingkat keyakinan terhadap suatu hipotesis yaitu 0,062 . Sedangkan pada kelas kontrol, kolom statistic merupakan nilai hitung uji normalitas yaitu 0,909 dengan kolom degree of freedom ( $d f$ ) atau derajat kebebasan yang merupakan jumlah sampel yaitu 19 siswa dengan kolom signifikan yang merupakan tingkat keyakinan terhadap suatu hipotesis yaitu 0,072 .

Berdasarkan hasil pengujian statistik menggunakan bantuan software Statistical Product and Service Solution (SPSS), untuk membaca uji Shapiro-Wilk hanya melihat pada kolom signifikansi. Signifikansi pada kelas eksperimen yaitu 0,062 dan untuk kelas kontrol yaitu 0,072. Karena signifikansi kelas eksperimen dan kelas kontrol >0,05 maka dapat disimpulkan bahwa data penelitian berdistribusi normal.

b. Uji Homogenitas

Tabel 4. Uji Homogenitas Pretest

Test of Homogeneity of Variances

PRETEST
\begin{tabular}{|r|r|r|r|}
\hline $\begin{array}{c}\text { Levene } \\
\text { Statistic }\end{array}$ & df1 & df 2 & Sig. \\
\hline, 361 & 1 & 36 &, 552 \\
\hline
\end{tabular}

Berdasarkan tabel uji homogenitas pretest diketahui hasil uji homogenitas pretest. Pada kolom levene statistic yang merupakan angka dari sebaran populasi yaitu
0,361 dengan kolom degree of freedom1 (dfl) yang merupakan jumlah variabel -1 yaitu $2-1=1$ dan degree of freedom2 (df2) yang merupakan jumlah populasi - jumlah variabel yaitu $38-2=36$ dengan signifikan yang merupakan tingkat keyakinan terhadap suatu hipotesis yaitu 0,552 .

Berdasarkan hasil pengujian statistik menggunakan bantuan software Statistical Product and Service Solution (SPSS), untuk membaca uji homogenitas hanya melihat pada kolom signifikansi. Signifikansi nilai pretest kelas eksperimen dan kelas kontrol yaitu 0,552. Karena signifikansi kelas eksperimen dan kelas kontrol >0,05 maka dapat disimpulkan bahwa varian kedua kelompok data pretest kelas eksperimen dan kelas kontrol adalah homogen.

Tabel 5. Uji Homogenitas Posttest

Test of Homogeneity of Variances

POSTTEST
\begin{tabular}{|r|r|r|r|}
\hline $\begin{array}{l}\text { Levene } \\
\text { Statistic }\end{array}$ & df1 & df2 & Sig. \\
\hline, 099 & 1 & 36 &, 755 \\
\hline
\end{tabular}

Berdasarkan tabel uji homogenitas posttest diketahui hasil uji homogenitas posttest. Pada kolom levene statistic yang merupakan angka dari sebaran populasi yaitu 0,099 dengan kolom degree of freedom1 (dfl) yang merupakan jumlah variabel -1 yaitu $2-1=1$ dan degree of freedom2 ( $d f 2$ ) yang merupakan jumlah populasi - jumlah variabel yaitu $38-2=36$ dengan signifikan yang merupakan tingkat 
keyakinan terhadap suatu hipotesis yaitu 0,755 .

Berdasarkan hasil pengujian statistik menggunakan bantuan software Statistical Product and Service Solution (SPSS), untuk membaca uji homogenitas hanya melihat pada kolom signifikansi nilai posttest kelas eksperimen dan kelas kontrol diperoleh signifikansi 0,755 . Karena signifikansi kelas eksperimen dan kelas kontrol > 0,05 maka dapat disimpulkan bahwa varian kedua kelompok data posttest kelas eksperimen dan kelas kontrol adalah homogen.

\section{c. Uji T}

Jika persyaratan terpenuhi, artinya data yang dikumpulkan dari hasil penelitian telah berdistribusi normal dan homogen, maka dilakukan uji hipotesis penelitian. Pengujian hipotesis dimaksudkan untuk menguji apakah hipotesis yang telah diajukan peneliti diterima atau ditolak. Uji hipotesis ini didasarkan pada perbedaan hasil belajar dalam pengujian hipotesis tersebut.

Tabel 6. Deskripsi Data

\begin{tabular}{|l|l|c|c|}
\hline & KELAS & $\mathrm{N}$ & Mean \\
\hline POST & Eksperimen & 19 & 80,0000 \\
TEST & Kontrol & 19 & 71,5789 \\
\hline
\end{tabular}

Berdasarkan tabel deskripsi data diketahui deskripsi data pada kelas eksperimen dengan $\mathrm{N}$ yang merupakan jumlah sampel yaitu 19 siswa, dengan mean atau rata-rata yaitu 80,0000 . Sedangkan pada kelas kontrol $\mathrm{N}$ yang merupakan jumlah sampel yaitu 19 siswa, dengan mean atau rata-rata yaitu 71,5789.
Tabel 7. Uji Independent Sample T-Test (Postest)

\begin{tabular}{|c|c|c|c|c|c|c|c|c|}
\hline & \multicolumn{7}{|c|}{ t-test for Equality of Means } \\
\hline & & \multirow[t]{2}{*}{$\mathrm{t}$} & \multirow[t]{2}{*}{ Df } & \multirow[t]{2}{*}{$\begin{array}{l}\text { Sig } \\
\dot{(2-} \\
\text { tail } \\
\text { ed) }\end{array}$} & \multirow[t]{2}{*}{$\begin{array}{l}\text { Mea } \\
n \\
\text { Diff } \\
\text { eren } \\
\text { ce }\end{array}$} & \multirow[t]{2}{*}{$\begin{array}{c}\text { Std. } \\
\text { Erro } \\
r \\
\text { Diff } \\
\text { eren } \\
\text { ce }\end{array}$} & \multicolumn{2}{|c|}{$\begin{array}{c}95 \% \\
\text { Confidenc } \\
\text { e Interval } \\
\text { of the } \\
\text { Difference }\end{array}$} \\
\hline & & & & & & & $\begin{array}{c}\text { Lo } \\
\text { we } \\
\text { r }\end{array}$ & $\begin{array}{l}\text { Upp } \\
\text { er }\end{array}$ \\
\hline PO & $\begin{array}{l}\text { Equ } \\
\text { al } \\
\text { varia } \\
\text { nces } \\
\text { assu } \\
\text { med }\end{array}$ & $\begin{array}{l}2 \\
4 \\
5\end{array}$ & 36 & $\begin{array}{r}, 00 \\
3\end{array}$ & $\begin{array}{r}8,42 \\
105\end{array}$ & $\begin{array}{r}2,59 \\
477\end{array}$ & $\begin{array}{r}3,1 \\
58 \\
61\end{array}$ & $\begin{array}{r}13,6 \\
8349\end{array}$ \\
\hline $\begin{array}{l}\text { ST } \\
\text { TE } \\
\text { ST }\end{array}$ & $\begin{array}{l}\text { Equ } \\
\text { al } \\
\text { varia } \\
\text { nces } \\
\text { not } \\
\text { assu } \\
\text { med }\end{array}$ & $\begin{array}{l}3 \\
2 \\
2 \\
4 \\
5\end{array}$ & $\begin{array}{r}36 \\
00 \\
0\end{array}$ & $\begin{array}{r}, 00 \\
3\end{array}$ & $\begin{array}{r}8,42 \\
105\end{array}$ & $\begin{array}{r}2,59 \\
477\end{array}$ & $\begin{array}{r}3,1 \\
58 \\
61\end{array}$ & $\begin{array}{r}13,6 \\
8349\end{array}$ \\
\hline
\end{tabular}

$\begin{array}{lcr}\quad \text { Berdasarkan } & \text { tabel } & \text { uji } \\ \text { independent } & \text { sample } & t \text {-test } \\ \text { (postest)diketahui } & \text { hasil } & \text { uji }\end{array}$
independent sample t-test. Pada uji independent sample t-test kolom yang dilihat yaitu equal variances assumed yaitu diasumsikan varian yang sama. Alasan melihat kolom tersebut karena data penelitian yang didapat memiliki varian yang sama atau homogen. Pada kolom $\mathrm{t}$ merupakan nilai $\mathrm{t}_{\text {hitung }}$ yaitu 3,245 dengan kolom degree of freedom (df) atau derajat kebebasan yang merupakan jumlah populasi - 2 variabel yaitu 36 dan sig. (2-tailed) yang merupakan suatu perumusan hipotesis dua arah yang tidak diketahui ada tidaknya suatu pengaruh yaitu sebesar 0,003. Pada kolom mean difference yang merupakan rata-rata kedua kelompok yaitu 8,42105 lalu pada kolom std. 
Error difference atau standart kesalahan baku yang merupakan nilai yang digunakan untuk mengukur nilai ketepatan rata-rata kedua kelompok yaitu 2,59477 dengan kolom 95\% confidence interval of the difference yang merupakan prensentase jarak untuk menunjukkan apakah penilaian perubahan tersebut secara statistik bermakna dengan lower atau nilai rendah yaitu 3,15861 dan upper atau nilai atas yaitu 13,68349 .

Berdasarkan hasil pengujian statistik menggunakan bantuan software Statistical Product and Service Solution (SPSS) v21-64 bit for windows, untuk membaca uji hipotesis independent sample t-test hanya melihat pada kolom sig. (2tailed) yaitu sebesar 0,003. Karena sig (2-tailed) $0,003<0,05$ maka $\mathrm{H}_{0}$ ditolak $\mathrm{H}_{\mathrm{a}}$ diterima, sehingga dapat disimpulkan bahwa ada pengaruh kooperatif tipe Think Pair Share terhadap hasil tematik belajar siswa SDN 2 Kedamean Kabupaten Gresik. Hasil penelitian terbukti dengan kemampuan akhir kedua kelas dapat diketahui melalui posttest yang dilakukan setelah kedua kelas mendapat perlakuan model pembelajaran. Analisis data nilai posttest menunjukkan bahwa perolehan rata-rata kelas eksperimen yaitu 80,00 dan nilai rata-rata kelas kontrol yaitu 71,57. Hasil analisis uji independent sample t-test menunjukkan bahwa nilai signifikan $0,003<0,05$. Hal ini menunjukkan bahwa ada pengaruh kooperatif tipe Think Pair Share terhadap hasil belajar tematik siswa kelas III SDN 2 Kedamean Kabupaten Gresik.

\section{SIMPULAN}

Hasil penelitian yang didasarkan pada pengolahan data dan pengujian hipotesis, maka dapat diperoleh simpulan hasil uji independent sample t-test yang diperoleh yaitu $0,003<$ 0,05 . Dengan demikian maka $\mathrm{H}_{0}$ ditolak dan $\mathrm{H}_{\mathrm{a}}$ diterima yang artinya ada pengaruh kooperatif tipe Think Pair Share terhadap hasil belajar tematik siswa SDN 2 Kedamean Kabupaten Gresik.

\section{DAFTAR RUJUKAN}

Amir, Taufiq M. 2010. Inovasi Pendidikan Melalui Problem Based Learning: Bagaimana Pendidik Memberdayakan Pembelajar di Era Pengetahuan. Jakarta: Kencana.

Ngalimun. 2012. Strategi dan Model Pembelajaran. Yogyakarta: Aswaja Pressindo.

Riyanto, Yatim. 2007. Metodologi Penelitian Pendidikan Kualitatif dan Kuantitatif. Surabaya: Unesa University Press.

Sawono, Jonathan. 2013. ModelModel Linier dan Non-Linier dalam IBM SPSS 21. Jakarta: PT Elex Media Komputindo.

Shoimin, Aris. 2014. Model Pembelajaran Inovatif dalam Kurikulum 2013. Yogyakarta: AR-Ruz Media.

Slavin, Robert, E. 2010. Cooperative Learning Teori, Riset dan Praktik. Bandung: Nusa Media.

Sugiyono. 2010. Metode Penelitian Kuantitatif Kualitatif dan $R$ \& $D$. Bandung: Alfabeta. 
Trapsila: Jurnal Pendidikan Dasar | p-ISSN 2685-7642

Vol. 01 No. 01 Juli 2019

Sugiyono. 2012. Metode Penelitian Kuantitatif Kualitatif dan $R$ \& $D$. Bandung: Alfabeta.

Sukmadinata, Nana S. 2010. Pengembangan Kurikulum: Teori dan Praktek. Bandung: PT Remaja Rosdakarya.
Suprijono, Agus. 2014 Cooperative Learning Teori \& Aplikasi PAIKEM. Yogyakarta: Pustaka Pelajar.

Susanto. 2013. Teori Belajar dan Pembelajaran di Sekolah Dasar. Jakarta: PT Remaja Rosdakarya. 